\title{
PERFORMANCE OF SOME GENOTYPES OF COTTON UNDER CONVENTIONAL AND LATE PLANTING DATES
}

\author{
Abdel-Hafez ${ }^{1}$,A.G.,A.E.I. Darwesh ${ }^{2}$, F.A. Sorour ${ }^{1}$ and AmI S. \\ Abdel-Hafez ${ }^{2}$ \\ 1 Agronomy Department, Faculty of Agriculture, Kafr EL-Sheikh, Egypt \\ 2 Cotton Research Institute, Agric. Res. Center, Giza, Egypt
}

\begin{abstract}
Planting date is one of the most important management factors involved in producing high-yielding and high quality cotton. However, cotton growers often lost the optimal planting date waiting for the harvest of preceding fullseason winter crops. So, cotton breeders look forward in selecting some adapted genotypes for sowing at late planting date to enable cotton growers to make better land use by planting a winter crop or take frequent cuts of Egyptian clover before cotton planting. There for, the present investigation aimed to study the behavior of genotypes, general and specific combining ability under late planting date and select the suitable parents and combinations for late planting date. In 2014 growing season seven parents were crossed in a half diallel mating design at Sakha. In 2015 growing season the seven parents and their 21 crosses were evaluated in two planting dates: the first date was in the last week of April (conventional planting date) and the second planting date was in the last week of May (late planting date). The results showed that the parents (Suven, CB58 and Giza 93) were good combiner under late planting dates. and the best crosses were Kar.2 x G.94, Suven x \{ [ G.84 x ( G.70 x G.51 B ) ] x S62 \}, Suven x G.93 and CB58 X G.93 for seed cotton yield under late planting date. The parent $G .93$ and crosses Suven x G.93, C.B58 x G.93 and \{ [ G.84 x ( G.70 x G.51 B ) ] TJx S62 \} x G.93 exhibited the best values for fiber traits. Cotton breeders can use these hybrids to improve breeding programs in order to select the most promising genotypes for late-planting date. These crosses could be exploited in breeding program aiming to improve late-planting tolerance. It will produce valuable economic value for farmer and nation.
\end{abstract}

Keywords; cotton, yield and fiber traits, late planting date, general and specific combining ability.

\section{INTRODUCTION}

Cotton is one of the most important fiber crops in the world as well as in Egypt. In Egypt, cotton growers got used to delay cotton planting beyond end of April in order to have one extra boll weight, seed index, lint percentage, number of days to cut from clover. Tunio et al. (1992) suggested early sowing of cotton $\left(15^{\text {th }}\right.$ April to $15^{\text {th }}$ May), while Soomro et al. (2000) reported that $15^{\text {th }}$ May sown crop gave increased boll weight and seed cotton yield per hectare, but reported adverse 
effects of delayed sowing on seed cotton yield . Elayan et al. ( 2015 ) stated that the response to delay of planting was negative with quadratic and linear functions in the first and second seasons. Yehia and Hassan (2015) showed that the additive dominance model was adequate to demonstrate the genetic variation and its importance on the inheritance of most studied traits. Non-allelic gene interaction was operating in the control of genetic variation in most studied traits. Also, the inheritance of all studied traits was controlled by additive and nonadditive genetic effects, but dominance gene effects play the major role in controlling the genetic variation of most of studied traits for all studied crosses. Genetic analysis using generation means has been used in cotton breeding to estimate the type of gene action controlling quantative traits. Amein et al. (2013) found that mean squares due to general combining ability (GCA) and specific combining ability (SCA) were also significant. Variances due to SCA were greater than GCA for all studied traits, indicating the predominance of non-additive gene action. Khan et al. (2011) using $6 \times 6 F_{1}$ half diallel cross found that mean squares due to GCA and SCA were highly significant for lint percentage and seed cotton yield. Mean squares due to GCA were higher in magnitude than those due to SCA for all traits and their inheritance was mainly governed by additive type of gene action and partially by non-additive. Linghe and William (2015) found that GCA effects for lint yield and two yield component were different between delayed planting. Also, combining ability effects for fiber properties were similar between treatments of planting date. Green and Culp (1990) found that two germplasm lines ranked at top for normal planting, but ranked nearly at bottom for the late planting. On the other hand, all cultivars used in delaying planting were selected under conventional planting, thus information about genetic variance of parents, GCA, and SCA under adverse environment will be help for the necessary testing of parents and crosses before their use in breeding cultivars to suitable the delayed planting in future. These studies indicate the necessity to develop cotton cultivars with high stability for agronomic performance in late planting growing system. Therefore, the main objectives of the present study are to study the behavior of genotypes, general and specific combining ability under late planting dates and to select the suitable parents and combinations for late planting date of cotton.

\section{MATERIAS AND METHODS}

Genetic materials contained seven parents and $21 \mathrm{~F} 1 \mathrm{~s}$.

Karsheneski-2 (Kar.2): It is a Russian variety. It is branchless, low in yield, lint percentage, boll weight, leaf area index, position of first fruiting node and early maturity. 
Suven: It's an Indian variety. It's a long staple. It's characterized by earliness, heavy boll weight, high yield and lowest in growth habit traits.

C.B58: This is an American-Egyptian cotton variety. It's characterized by high yield.

Giza 94 ( G.94 ): It's an Egyptian staple cultivar characterized by high lint percentage, earliness and high yielding.

[ G.84 x ( G.70 x G.51 B ) ] x S62 : It is a promising line cross. An extra-long staple, high , fiber length and fiber strength .

Giza 80 ( G.80 ): It's an Egyptian long staple cultivar selected for upper Egypt, characterized by fine and short fiber and lower fiber and more tolerant to high temperature.

Giza 93 ( G.93 ): It's an Egyptian extra-long staple, extra fine, strong lint and earliness.

In 2014 growing season, the seven cotton genotypes G.80, G.93, G.94, Karsheneski-2, Suven , C.B58 and promising line from the cross [ G.84 x ( G.70 × G.51 B ) ] x S62 representing a range of yield and fiber quality were ( hand) crossed in a half diallel mating scheme to obtain 21 single crosses at Sakha Agricultural Research Station, Agricultural Research Center (ARC).

In 2015 growing season, The Seven parents and their $21 \mathrm{~F} 1$ crosses were evaluated at two planting date representing different environments i.e. conventional and late planting date (stress conditions) at Sakha Agricultural Research Station. A randomized complete blocks design with four replications was devoted. Each plot was represented by one row $5 \mathrm{~m}$. long and $0.7 \mathrm{~m}$. wide. Seeds were planted on one side of the ridge at $30 \mathrm{~cm}$. hill spacing with two plants per hill. Data were recorded on individual guarded plants chosen at random from each plot in middle ridge for $\mathrm{F} 1$ and their parents.

Collected data: The collected data were recorded for the following characters:

1- Plant height $(\mathrm{cm})$

2- Earliness index (\%)

3- Lint percentage ( \%)

4- Seed cotton yield ( $)$ / plant value )
5- Boll weight $(\mathrm{g})$

6- Fiber length ( $\mathrm{mm}$ )

7- Fiber strength ( $\mathrm{g} /$ plant $)$

8- fiber fineness ( Micronaire

Analysis of variance:

The analyses of variance for each planting date over the two environments were computed as outlined by Snedécor and Cochran (1982). The analysis of variance for combining ability was done according to Griffing's (1956) method II model I. 
RESULTS AND DISCUSSIONS

The results in Table (1) exhibited that genotypes, parents and crosses were highly significant at the conventional planting dates for all characters except for crosses and parent versus crosses for earliness index and genotypes and parent versus crosses for boll weight. The same trend was found at late planting date except for parents for plant height and seed cotton yield and parent versus crosses for boll weight and lint percentage. These results were in harmony with those reported by Ali and El-Sayed (2001) and Elayan et al. (2008).

Also, the mean squares of general combining ability and specific combining ability were significant or highly significant for all characters in both planting dates except for boll weight at the conventional planting date. These results indicated the importance of both additive and dominance effect on inheritance of these characters, as well as using recurrent selection and intermating in early generation to improve these characters. These results support the findings of Ahuja and Tuteja (2000) and Tuteja et al. (2003). On other hand, all values of mean squares were significant for fiber traits (fiber length, fiber strength and fineness) in both environments except for parents for fiber strength at the conventional date. These results are in harmony with those reported by Wenqing et al. (2012).

Table 1: Mean squares of seven parents and $F_{1}$ for yield, yield components and fiber traits in the two planting dates

\begin{tabular}{|c|c|c|c|c|c|c|c|c|c|c|c|}
\hline \multirow[b]{2}{*}{ S.o.v } & \multirow{2}{*}{$\begin{array}{l}\text { D. } \\
\mathbf{F}\end{array}$} & \multicolumn{2}{|c|}{ Plant height (cm) } & \multicolumn{2}{|c|}{ Earliness index (\%) } & \multicolumn{2}{|c|}{ Lint percentage (\%) } & \multicolumn{2}{|c|}{$\begin{array}{l}\text { Seed cotton yield } \\
\text { (g)/plant }\end{array}$} & \multicolumn{2}{|c|}{ Boll weight (g) } \\
\hline & & $\mathrm{D}_{1}$ & $\mathrm{D}_{2}$ & $\mathrm{D}_{1}$ & $\mathrm{D}_{2}$ & $\mathrm{D}_{1}$ & $\mathrm{D}_{2}$ & $\mathrm{D}_{1}$ & $\mathrm{D}_{2}$ & $\mathrm{D}_{1}$ & $\mathrm{D}_{2}$ \\
\hline Replications & 3 & $910.40^{\star \star}$ & 235.90 & 140.20 & 32.95 & $5.50^{\star \star}$ & 3.20 & $593.77^{\star \star}$ & $85.83^{\star *}$ & 0.19 & 0.16 \\
\hline Genotypes & 27 & $612.30^{\star \star}$ & $516.40^{\star \star}$ & $646.90^{\star \star}$ & $508.60^{\star \star}$ & $19.10^{\star \star}$ & $20.99^{\star \star}$ & $129.12^{\star \star}$ & $27.04^{\star \star}$ & 0.29 & $0.52^{\star \star}$ \\
\hline Parents & 6 & $300.90^{\star *}$ & 188.40 & $1321.60^{\star \star}$ & $773.90^{\star \star}$ & $35.50^{\star \star}$ & $40.4^{\star \star}$ & $56.16^{\star \star}$ & 5.78 & $0.30^{\star \star}$ & $0.77^{\star \star}$ \\
\hline Crosses & 20 & $652.60^{\star \star}$ & $502.10^{\star}$ & 187.70 & $281.60^{\star \star}$ & $14.80^{\star *}$ & $16.1^{\star \star}$ & $110.45^{\star \star}$ & $30.96^{\star *}$ & $0.31^{\star \star}$ & $0.47^{\star \star}$ \\
\hline $\begin{array}{c}\text { Parent versus } \\
\text { crosses }\end{array}$ & 1 & $1673.60^{\star *}$ & $2771.10^{\star \star}$ & 49.20 & $4356.60^{\star \star}$ & $8.50^{\star \star}$ & 3.2 & $940.3^{\star \star}$ & $76.13^{\star \star}$ & 0.05 & 0.18 \\
\hline G.C.A & 6 & $1605.60^{\star \star}$ & $725.60^{\star \star}$ & $1312.50^{\star \star}$ & $958.40^{\star \star}$ & $59.50^{\star \star}$ & $62.4^{\star \star}$ & $177.3^{\star \star}$ & $24.40^{\star \star}$ & $0.50^{\star}$ & $1.10^{\star \star}$ \\
\hline S.C.A & 21 & $328.50^{*}$ & $456.70^{\star \star}$ & $456.70^{\star \star}$ & $380.10^{\star \star}$ & $7.60^{\star \star}$ & $9.2^{\star \star}$ & $115.3^{\star \star}$ & $27.80^{\star \star}$ & 0.20 & $0.30^{\star}$ \\
\hline Error & 81 & 170.30 & 145.80 & 117.50 & 99.20 & 0.95 & 1.66 & 10.66 & 7.73 & 0.21 & 0.17 \\
\hline
\end{tabular}


Table 1: Cont.

\begin{tabular}{|c|c|c|c|c|c|c|c|}
\hline \multirow{2}{*}{ Fiber strength } & \multirow[b]{2}{*}{$\begin{array}{l}\text { D. } \\
\text { F }\end{array}$} & \multicolumn{2}{|c|}{ Fiber length $(\mathrm{mm})$} & \multicolumn{2}{|c|}{ Fiber strength (g/tex) } & \multicolumn{2}{|c|}{$\begin{array}{l}\text { Fiber fineness } \\
\text { Micronaire value ) }\end{array}$} \\
\hline & & $\mathrm{D}_{1}$ & $\mathrm{D}_{2}$ & $\mathrm{D}_{1}$ & $\mathrm{D}_{2}$ & $\mathrm{D}_{1}$ & $\mathrm{D}_{2}$ \\
\hline Replications & 3 & 0.33 & 0.73 & 1.32 & 1.82 & 0.001 & 0.02 \\
\hline Genotypes & 27 & $5.62^{\star \star}$ & $4.95^{\star \star}$ & $7.39^{\star}$ & $10.69^{\star *}$ & $0.22^{\star \star}$ & $0.24^{\star \star}$ \\
\hline Parents & 6 & $3.88^{\star \star}$ & $9.61^{\star \star}$ & 1.93 & $6.51^{\star \star}$ & $0.53^{\star \star}$ & $0.38^{\star \star}$ \\
\hline Crosses & 20 & $3.49^{\star \star}$ & $2.82^{*}$ & $6.61^{\star}$ & $10.71^{\star \star}$ & $0.13^{\star \star}$ & $0.18^{\star \star}$ \\
\hline Parent versus crosses & 1 & $58.74^{\star \star}$ & $19.55^{\star \star}$ & $52.37^{\star \star}$ & $21.86^{* *}$ & $2.67^{\star \star}$ & $0.57^{\star \star}$ \\
\hline G.C.A & 6 & $9.3^{* \star}$ & $12.1^{\star \star}$ & $8.9^{*}$ & $12.1^{*}$ & $0.76^{\star \star}$ & $0.46^{\star \star}$ \\
\hline S.C.A & 21 & $4.6^{\star \star}$ & $2.8^{\star \star}$ & $6.8^{*}$ & $9.2^{\star}$ & $0.07^{\star}$ & $0.20^{*}$ \\
\hline Error & 81 & 0.94 & 0.56 & 3.69 & 4.26 & 0.04 & 0.06 \\
\hline
\end{tabular}

$\mathrm{D}_{1}$ and $\mathrm{D}_{2}$ conventional and late planting dates.

${ }^{*},{ }^{* *}$ Significant and highly significant at 0.05 and 0.01 probability levels, respectively.

Significance of genotypes indicated that there are variability in their performance under the two conditions, therefore, the mean performance for all genotypes for the studied characters are presented in Table (2). The results showed that the cross Kar. 2 x G.80 then Kar.2 x CB58 gave the best desirable values for plant height at the conventional planting date. Meanwhile, the cross Kar. 2 x CB58 then Kar. 2 x G.94 gave the best desirable values ( short ) for plant height at the late planting date. On the other hand, the cross Suven $\times$ G.80 then Suven $\times\{$ [ G.84 x ( G.70 x G.51 B ) ] x S62 $\}$ gave the highest highly significant positive difference between the conventional planting date and the late one and the crosses CB58 $\times$ \{ [ G.84 x ( G.70 x G.51 B ) ] x S62 \}, CB58 x G.80, Suven x G.93 and the parent [ G.84 x ( G.70 x G.51 B ) ] x S62 gave significant positive difference between the conventional planting date and the late one. Previous results showed that the crosses derived using Kar.2 gave the desirable values ( shorter ) for plant height. Thus, the breeder can use this variety to improve plant height in segregating generations, the interaction between genotypes and environment attributed desirable crosses values for Suven x $\{[\mathrm{G} .84 \times(\mathrm{G} .70 \times \mathrm{G} .51 \mathrm{~B})] \times \mathrm{S} 62\}$, Suven $\times$ G.80, Suven x G.93 , CB58 x [ G.84 x ( G.70 x G.51 B ) ] x S62 and CB58 x G.80 and [ G.84 x ( G.70 x G.51 B ) ] x S62 gave the most desirable values, where the plant height was shorter under late planting .

For earliness index the cross Kar. 2 x G.94 then Kar. 2 x Suven gave the highest values at the conventional planting date, while the cross Kar. 2 x C.B58 then Kar.2 x \{ [ G.84 x ( G.70 x G51 B ) ] x S62 \} gave the highest values at the late planting date, the interaction 
between genotypes and environment caused lateness, the cross Kar. 2 × CB58 and the parents Kar.2 and \{ [ G.84 x ( G.70 x G51 B ) ] x S62 \} gave the highest highly significant negative and the parents Kar.2 and CB58 and the cross Suven x G.94, respectively, gave significant negative difference between two planting date (lateness ).

The parent G.94 and the cross Kar.2 x G.80 gave the highest value for lint percentage at the conventional planting date, meanwhile, the parent G.94 and the cross G.80 x G.93 gave the highest value for lint percentage at the late planting date. On the other hand, the crosses \{ [ G.84 x ( G.70 x G51 B ) ] x S62 \} × G.80 and Kar.2 × Suven gave the highest highly significant positive difference between two planting dates, while, the crosses Kar. 2 × CB58 and G.80 × G.93 gave the highest highly significant negative difference between both planting dates . The crosses Kar. $2 \times$ G. 80 , Kar.2 $\times$ Suven, Suven $\times$ G.93 , \{ [ G. $84 \times(\mathrm{G} .70 \times \mathrm{G} 51$ B $)] \times \mathrm{S} 62\} \times \mathrm{G} .80$ and \{ [ G.84 × ( G.70 × G51 B ) ] x $S 62\} \times$ a.93 differed in lint percentage from planting date to another and gave highly significantly values for lint percentage at the conventional planting date, while the crosses G.94 × \{ [ G.84 × ( G.70 x G51 B ) ] x S62 \}, G.80 x G.93 , Kar.2 x G.94 and G.94 x G.80 gave the highest values for lint percentage at the late planting date , however, its values were lower than that of G.94 . Lint percentage of G. 80 was not negatively affected by delaying of planting date. For difference between conventional date and late date, the interaction between genotypes and environment gave undesirable values for Kar. 2 x Suven, Kar. 2 x G.80, Suven x G.94, Suven x G.93, G.94 x G.93 , \{[ G.84 x (G.70 x G51 B ) ] x S62 \} x G.80) and \{[ G.84 × ( G.70 x G51 B ) ] x S62 \} × G.93, meanwhile, Kar.2 × CB58 and G.80 x G.93 and the parent [ G.84 x ( G.70 x G51 B ) ] x S62 gave desirable values.

Kar. 2 x G.94 , Suven x CB58 , Kar.2 × \{ [ G.84 x ( G.70 x G51 B ) ] x S62\}, Suven x \{[ G.84 x ( G.70 x G51 B ) ] x S62 \}, Kar.2 x G.94, Suven x G.80, CB58 x G.94, CB58 × [ [ G.84 x (G.70 x G51 B ) ] x S62 \}, CB58 x G.80, CB58 x G.93 , G.94 x \{ [ G.84 x ( G.70 × G51 B ) ] x S62 \}, G.94 x G.80, Kar.2 x G.93 and parents Kar.2, Suven , CB58 , G.94 , G.80 and G.93 did not show reduction in lint percentage at late planting date, showing promising materials for breeding for late planting date.

It is not worthy that mean performance of most genotypes at the late planting date obtained lower seed cotton yield than that of the conventional sowing date. The cross Kar. 2 x G.94 then Suven x G.94 gave its highest values for seed cotton yield at the conventional planting date, meanwhile, the crosses CB58 x G.93 and Suven x G.93 gave its highest values for seed cotton yield at the late planting date. The parents CB58 , G.80 and [ G.84 x ( G.70 x G51 B ) ] x S62 and the 
crosses CB58 x G.93 , CB58 x G.80 , G.94 × \{ [ G.84 × ( G.70 × G51 B ) ] x S62 \}, Suven x \{[ G.84 x ( G.70 x G51 B ) ] x S62 $\}$ and \{ [ G.84 x ( G.70 × G51 B ) ] x S62 \} × G.80 gave statistically not significantly differing seed cotton yield between the two planting dates.

Table 2: The mean performances of seven parents and $\mathrm{F} 1$ for yield, yield components and fiber traits in two planting dates

\begin{tabular}{|c|c|c|c|c|c|c|c|c|c|c|c|c|c|c|c|}
\hline \multirow{2}{*}{ Genotypes } & \multicolumn{3}{|c|}{ Plant height (cm) } & \multicolumn{3}{|c|}{ Earliness index $(\%)$} & \multicolumn{3}{|c|}{ Lint percentage $(\%)$} & \multicolumn{3}{|c|}{ Seed cotton yield $(\mathrm{g}) /$ plant } & \multicolumn{3}{|c|}{ Boll weight $(g)$} \\
\hline & $\mathrm{D}_{1}$ & $\mathrm{D}_{2}$ & $D_{1}-D_{2}$ & $\mathrm{D}_{1}$ & $\mathrm{D}_{2}$ & $D_{1}-D_{2}$ & $D_{1}$ & $\mathrm{D}_{2}$ & $D_{1}-D_{2}$ & $D_{1}$ & $\mathrm{D}_{2}$ & $D_{1}-D_{2}$ & $\mathrm{D}_{1}$ & $\mathrm{D}_{2}$ & $D_{1}-D_{2}$ \\
\hline Kar. $2 \times$ Suven & 168.75 & 166.25 & 2.50 & 83.75 & 86.95 & -3.20 & 35.20 & 32.38 & $2.83^{* *}$ & 29.76 & 16.82 & $12.94^{* *}$ & 3.43 & 3.48 & -0.05 \\
\hline Kar. $2 \times$ C.B58 & 166.25 & 158.75 & 7.50 & 71.69 & 91.92 & $-20.23^{* *}$ & 33.05 & 36.50 & $-3.45^{* *}$ & 30.55 & 17.92 & $12.63^{* *}$ & 3.80 & 3.15 & $0.65^{\star}$ \\
\hline Kar. $2 \times$ G. 94 & 172.50 & 162.50 & 10.00 & 84.94 & 88.58 & -3.64 & 38.05 & 38.98 & -0.92 & 36.72 & 19.76 & $16.96^{* *}$ & 3.58 & 3.00 & 0.58 \\
\hline 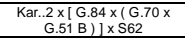 & 171.25 & 166.25 & 5.00 & 81.51 & 90.62 & -9.11 & 33.48 & 34.33 & -0.85 & 29.98 & 16.19 & $13.79^{* *}$ & 3.43 & 2.80 & $0.63^{*}$ \\
\hline Kar. $2 \times$ G. 80 & 163.75 & 170.00 & -6.25 & 79.07 & 83.35 & -4.28 & 39.73 & 37.03 & $2.70^{* *}$ & 27.93 & 13.59 & $14.34^{* *}$ & 3.08 & 3.28 & -0.20 \\
\hline Kar. $2 \times$ G.93 & 173.75 & 168.75 & 5.00 & 78.32 & 83.77 & -5.45 & 35.48 & 34.33 & 1.15 & 29.84 & 16.64 & $13.20^{* *}$ & 3.30 & 2.65 & $0.65^{*}$ \\
\hline Suven $\times$ C.B58 & 188.75 & 197.50 & -8.75 & 74.58 & 86.74 & -12.16 & 33.80 & 34.15 & -0.35 & 28.41 & 16.09 & $12.32^{* *}$ & 3.68 & 3.20 & 0.48 \\
\hline Suven x G. 94 & 196.25 & 178.75 & 17.50 & 72.20 & 86.96 & $-14.76^{*}$ & 38.75 & 36.70 & $2.05^{*}$ & 32.29 & 18.47 & $13.82^{* *}$ & 3.53 & 4.10 & -0.57 \\
\hline $\begin{array}{c}\text { Suven } \times[\text { G. } .84 \times(\mathrm{G} .70 \times \\
\text { G. } 51 \text { B })] \times \text { S62 } \\
\end{array}$ & 198.75 & 175.00 & $23.75^{* \star}$ & 78.10 & 70.37 & 7.72 & 37.28 & 37.28 & 0.00 & 23.93 & 20.01 & 3.92 & 4.30 & 3.50 & $0.80^{*}$ \\
\hline Suven $\times$ G. 80 & 203.75 & 178.75 & $25.00^{* *}$ & 71.59 & 70.08 & 1.52 & 36.70 & 37.05 & -0.35 & 21.81 & 14.17 & $7.65^{* *}$ & 3.68 & 3.30 & 0.38 \\
\hline Suven $\times$ G.93 & 197.50 & 178.75 & $18.75^{*}$ & 75.16 & 87.48 & -12.32 & 34.33 & 32.13 & $2.20^{*+*}$ & 28.81 & 20.96 & $7.84^{* *}$ & 4.13 & 3.80 & 0.33 \\
\hline C.B58 $\times$ G. 94 & 187.50 & 183.75 & 3.75 & 62.64 & 69.63 & -6.99 & 35.65 & 35.10 & 0.55 & 23.02 & 13.66 & $9.35^{* *}$ & 3.80 & 3.55 & 0.25 \\
\hline $\begin{array}{c}\text { C.B58 } \times[\text { G. } 84 \times(\mathrm{G} .70 \times \\
\text { G. } 51 \text { B })] \times \text { S62 } \\
\end{array}$ & 195.00 & 173.75 & $21.25^{*}$ & 67.30 & 78.63 & -11.32 & 36.93 & 35.58 & 1.35 & 24.48 & 13.93 & $10.55^{\text {t* }}$ & 3.73 & 3.60 & 0.13 \\
\hline C.B58 x G. 80 & 206.25 & 185.00 & $21.25^{*}$ & 59.51 & 65.21 & -5.69 & 37.00 & 35.78 & 1.23 & 17.58 & 15.33 & 2.25 & 3.58 & 3.53 & 0.05 \\
\hline C.B58 x G.93 & 197.50 & 180.00 & 17.50 & 81.39 & 87.90 & -6.51 & 34.25 & 33.53 & 0.72 & 24.72 & 23.95 & 0.77 & 3.68 & 3.55 & 0.13 \\
\hline $\begin{array}{c}\text { G. } 94 \times[\text { G. } 84 \times(\mathrm{G} .70 \times \\
\text { G. } 51 \text { B })] \times \text { S62 }\end{array}$ & 196.25 & 188.75 & 7.50 & 69.76 & 82.38 & -12.63 & 37.73 & 37.48 & 0.25 & 17.86 & 14.07 & 3.79 & 3.88 & 3.50 & 0.38 \\
\hline G. $94 \times$ × G. 80 & 190.00 & 175.00 & 15.00 & 69.90 & 65.53 & 4.37 & 38.00 & 38.10 & -0.10 & 21.54 & 13.24 & $8.30^{* *}$ & 3.93 & 3.63 & 0.30 \\
\hline G. $94 \times$ G.93 & 183.75 & 173.75 & 10.00 & 83.35 & 73.21 & 10.14 & 36.63 & 34.58 & $2.05^{*}$ & 21.56 & 15.87 & $5.69^{* \star}$ & 3.65 & 3.48 & 0.18 \\
\hline $\begin{array}{c}{[\mathrm{G} .84 \times(\mathrm{G} .70 \times \mathrm{G} .51 \mathrm{~B})] \times} \\
\mathrm{S} 62 \times \mathrm{G} .80\end{array}$ & 190.00 & 193.75 & -3.75 & 68.80 & 77.11 & -8.31 & 39.58 & 36.48 & $3.10^{* *}$ & 16.79 & 15.28 & 1.51 & 3.45 & 3.73 & -0.27 \\
\hline $\begin{array}{c}{[\mathrm{G} .84 \times(\mathrm{G} .70 \times \mathrm{G} .51 \mathrm{~B})] \times} \\
\mathrm{S} 62 \times \mathrm{G} .93\end{array}$ & 193.75 & 192.50 & 1.25 & 76.64 & 82.76 & -6.12 & 36.68 & 34.50 & $2.18^{* *}$ & 23.23 & 16.55 & $6.68^{* *}$ & 3.73 & 3.15 & 0.58 \\
\hline G. $80 \times$ G.93 & 188.75 & 197.50 & -8.75 & 73.67 & 81.53 & -7.86 & 36.80 & 39.53 & $-2.73^{* *}$ & 21.56 & 15.15 & $6.41^{* *}$ & 3.95 & 3.75 & 0.20 \\
\hline Karsheneski-2 & 186.25 & 186.25 & 0.00 & 54.31 & 73.50 & $-19.19^{*}$ & 32.60 & 33.50 & -0.90 & 16.39 & 12.65 & 3.73 & 3.50 & 3.00 & 0.50 \\
\hline Suven & 207.50 & 200.00 & 7.5 & 70.17 & 72.79 & -2.62 & 34.43 & 33.60 & 0.83 & 18.18 & 13.90 & $4.28^{*}$ & 3.75 & 3.48 & 0.28 \\
\hline C.B58 & 190.00 & 198.75 & -8.75 & 31.88 & 47.92 & $-16.04^{*}$ & 33.9 & 34.58 & -0.68 & 16.50 & 16.25 & 0.25 & 3.90 & 3.58 & 0.33 \\
\hline Giza 94 & 188.75 & 186.25 & 2.5 & 71.97 & 79.56 & .7 .59 & 40.63 & 41.68 & -1.05 & 19.57 & 14.76 & $4.81^{*}$ & 4.03 & 4.13 & -0.10 \\
\hline $\begin{array}{c}{[\mathrm{G} .84 \times(\mathrm{G} .70 \times \mathrm{G} .51 \mathrm{~B})] \times} \\
\mathrm{S} 62\end{array}$ & 205.00 & 183.75 & $21.25^{*}$ & 51.03 & 70.92 & $-19.89^{* *}$ & 34.33 & 36.48 & $-2.15^{\text {t* }}$ & 15.94 & 14.15 & 1.80 & 3.90 & 3.60 & 0.30 \\
\hline Giza 80 & 202.50 & 190.00 & 12.5 & 42.31 & 48.12 & -5.80 & 39.25 & 39.28 & -0.02 & 17.37 & 15.63 & 1.74 & 3.65 & 2.90 & $0.75^{\star}$ \\
\hline Giza 93 & 192.50 & 183.75 & 8.75 & 83.48 & 80.96 & 2.52 & 35.45 & 34.10 & 1.35 & 26.68 & 15.23 & $11.45^{\text {t* }}$ & 3.23 & 3.88 & -0.65 \\
\hline LS D. & $18.36(1)$ & $17.23(2)$ & $17.69(3)$ & 15.25 & 13.95 & 14.65 & 1.37 & 1.82 & 1.61 & 4.59 & 3.93 & 4.27 & 0.64 & 0.58 & 0.61 \\
\hline 0.01 & 24.34 & 22.84 & 23.45 & 20.22 & 18.50 & 19.42 & 1.82 & 2.41 & 2.13 & 6.09 & 5.20 & 5.66 & 0.85 & 0.76 & 0.81 \\
\hline 0.05 & & & & & & & & & & & & & & & \\
\hline 0.01 & & & & & & & & & & & & & & & \\
\hline
\end{tabular}

Thus the interaction between genotypes and planting date affected the performance of most crosses and parents in positive and negative directions, while some genotypes did not show statistical changes.

The cross Seven x \{ [ G.84 x ( G.70 x G51 B ) ] x S62 \} then Suven x G.93 gave its highest values for boll weight at the conventional planting date, meanwhile, the parent G.94 and the cross Suven x G.94 gave its highest values for boll weight at the late planting date. The mean boll weight of most genotypes at the late planting date was not significantly lower than that of the conventional planting date for most tested genotypes. However, Kar. $2 \times$ G.93, Kar. $2 \times$ C.B58, Kar. $2 \times\{$ [ G.84 x ( G.70 × G51 B ) ] × S62 \}, Suven x \{ [ G.84 × ( G.70 × G51 B ) 
] x S62 \} and the parent G.80 gave lower boll weight at late planting date. Fiber traits of genotypes were also studied under the two planting dates. The parents G.93 and G.80 and the crosses G.94 x G.93 , Kar.2 x Suven and Kar.2 x G.93 gave the highly significantly higher fiber length at conventional planting date compared to the late one. The parents G.93 and [ G.84 x ( G.70 x G51 B ) ] x S62 and the crosses $\{[\mathrm{G} .84 \times(\mathrm{G} .70 \times \mathrm{G} 51$ B $)$ ] x S62 $\} \times$ G.93 , C.B58 × G.94 and Suven $x$ G.93 gave high values for fiber length at the late sowing date. On the contrary, the cross C.B58 x G.94 and the parents G.93, G.80 and Suven in descending order gave highly significantly higher fiber length at late planting date compared to the conventional planting date. Seventeen genotypes were not been affected significantly by planting date.

Table 2: Cont.

\begin{tabular}{|c|c|c|c|c|c|c|c|c|c|}
\hline \multirow{2}{*}{ Genotypes } & \multicolumn{3}{|c|}{ Fiber length (mm) } & \multicolumn{3}{|c|}{ Fiber strength (g/tex) } & \multicolumn{3}{|c|}{ Fiber fineness ( Micronaire value } \\
\hline & $D_{1}$ & $D_{2}$ & $D_{1}-D_{2}$ & $\mathbf{D}_{1}$ & $D_{2}$ & $D_{1}-D_{2}$ & $\mathbf{D}_{1}$ & $\mathrm{D}_{2}$ & $D_{1}-D_{2}$ \\
\hline Kar.2 x Suven & 39.16 & 36.87 & $2.30^{\star \star}$ & 43.30 & 41.9 & 1.40 & 4.26 & 4.13 & 0.13 \\
\hline Kar.2 x C.B58 & 36.64 & 36.72 & $\begin{array}{ll}-0.08 \\
\end{array}$ & 39.25 & 42.2 & $-2.95^{\star}$ & 4.19 & 4.15 & 0.04 \\
\hline Kar.2 x G. 94 & 36.28 & 36.28 & 0.00 & 40.00 & 41.8 & -1.80 & 4.27 & 3.74 & $0.53^{\star \star}$ \\
\hline Kar.2 x [ G.84 x ( G.70 x G.51 B ) ] x S62 & 36.50 & 37.10 & -0.59 & 41.90 & 43.6 & -1.70 & 4.09 & 3.96 & 0.14 \\
\hline Kar.2x G.80 & 33.37 & 34.11 & -0.75 & 39.00 & 37.95 & 1.05 & 3.95 & 4.01 & -0.06 \\
\hline Kar.2 x G.93 & 38.39 & 36.56 & $1.84^{\star \star}$ & 39.70 & 40.5 & -0.80 & 3.64 & 3.53 & 0.11 \\
\hline Suven x C.B58 & 37.06 & 36.15 & 0.92 & 40.25 & 41.35 & -1.10 & 4.21 & 4.29 & -0.08 \\
\hline Suven x G. 94 & 37.71 & 36.02 & $1.69^{\star \star}$ & 44.15 & 41.15 & $3.00^{*}$ & 4.47 & 4.55 & -0.08 \\
\hline $\begin{array}{c}\text { SUVEN x [ G.84 x ( G.70 x G.51 B ) ] X } \\
\text { S62 }\end{array}$ & 37.62 & 36.39 & $1.23^{*}$ & 44.45 & 42.95 & 1.50 & 4.46 & 4.11 & $0.36^{*}$ \\
\hline Suven $\times$ G.80 & 36.48 & 36.25 & 0.23 & 43.05 & 40.5 & 2.55 & 4.09 & 4.15 & -0.06 \\
\hline Suven x G.93 & 37.49 & 37.98 & -0.49 & 40.35 & 47.5 & $-7.15^{\star \star}$ & 3.90 & 3.76 & 0.14 \\
\hline C.B58 x G. 94 & 35.36 & 38.07 & $-2.71^{\star \star}$ & 39.10 & 40.2 & -1.10 & 4.37 & 3.79 & $0.58^{\star \star}$ \\
\hline $\begin{array}{c}\text { C.B58 } \times[\text { G.84 x ( G.70 x G.51 B })] \times \\
\text { S62 }\end{array}$ & 36.86 & 36.39 & 0.47 & 42.95 & 39.85 & $3.10^{\star}$ & 4.35 & 4.27 & 0.08 \\
\hline C.B58 x G.80 & 35.64 & 36.30 & $\begin{array}{l}-0.66 \\
\end{array}$ & 42.95 & 44.25 & -1.30 & 4.10 & 4.39 & -0.30 \\
\hline C.B58 x G.93 & 37.15 & 37.94 & $\begin{array}{l}-0.79 \\
\end{array}$ & 41.80 & 41.05 & 0.75 & 3.91 & 4.01 & -0.10 \\
\hline G. $94 \times[$ G. $84 \times($ G. $70 \times$ G. 51 B $)] \times S 62$ & 35.98 & 36.08 & -0.10 & 41.30 & 38.5 & $2.80^{*}$ & 4.42 & 4.58 & -0.15 \\
\hline G. $94 \times$ G.80 & 35.41 & 33.38 & $2.03^{\star \star}$ & 42.80 & 37.5 & $5.30^{\star \star}$ & 4.30 & 4.46 & -0.16 \\
\hline G. $94 \times$ G.93 & 39.17 & 37.02 & $2.15^{\star \star}$ & 44.25 & 39.8 & $4.45^{\star \star}$ & 4.06 & 3.83 & 0.23 \\
\hline [ G.84 x ( G.70 x G.51 B ) ] x S62x G.80 & 36.32 & 35.56 & 0.76 & 44.25 & 40.9 & $3.35^{*}$ & 4.44 & 4.32 & 0.12 \\
\hline 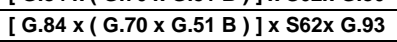 & 37.42 & 38.14 & -0.72 & 41.65 & 43.7 & -2.05 & 4.07 & 3.58 & $0.48^{\star \star}$ \\
\hline G. $80 \times$ x G.93 & 36.53 & 37.48 & -0.95 & 41.75 & 39.25 & 2.50 & 3.58 & 4.16 & $-0.57^{\star \star}$ \\
\hline Karsheneski-2 & 33.31 & 32.84 & 0.47 & 39.30 & 37.4 & 1.90 & 3.24 & 3.61 & $-0.38^{\star}$ \\
\hline Suven & 34.49 & 36.17 & $-1.68^{\star \star}$ & 39.75 & 38.5 & 1.25 & 3.90 & 4.10 & -0.20 \\
\hline C.B58 & 33.36 & 33.52 & -0.16 & 38.15 & 40.8 & -2.65 & 4.06 & 4.08 & -0.01 \\
\hline Giza 94 & 34.34 & 33.08 & $1.27^{\star}$ & 39.35 & 39.7 & -0.35 & 4.70 & 4.00 & $0.70^{\star \star}$ \\
\hline [ G.84 x ( G.70 x G.51 B ) ] x S62 & 36.03 & 36.81 & -0.77 & 39.90 & 40.95 & 0.45 & 4.25 & 4.50 & -0.25 \\
\hline Giza 80 & 32.91 & 34.91 & $-2.01^{\star \star}$ & 39.20 & 38.65 & 0.55 & 4.35 & 3.36 & $1.00^{\star \star}$ \\
\hline Giza 93 & 36.51 & 38.71 & $-2.20^{\star \star}$ & 39.95 & 42.7 & $-2.75^{\star}$ & 3.43 & 3.30 & 0.13 \\
\hline LS D. & $1.37(1)$ & $\begin{array}{l}1.051( \\
2)\end{array}$ & $1.22(3)$ & 2.54 & 2.90 & 2.73 & 0.27 & 0.36 & 0.32 \\
\hline 0.01 & 1.81 & 1.39 & 1.62 & 3.37 & 3.85 & 3.62 & 0.36 & 0.47 & 0.42 \\
\hline 0.05 & & & & & & & & & \\
\hline 0.01 & & & & & & & & & \\
\hline
\end{tabular}

$D_{1}$ and $D_{2}$ conventional and late planting dates.

(1) L.S.D for difference between two means at conventional planting date.

(2) L.S.D for difference between two means at late planting date.

(3) L.S.D for difference between means of two planting dates within same genotype. 
(4)

L.S.D for difference among any two means.

Concerning fiber strength, the cross Suven $\times\{$ [ $G .84 \times($ G.70 $\times$ G51 B ) ] x S62 $\}$ then $\{[\mathrm{G} .84 \times(\mathrm{G} .70 \times \mathrm{G} 51$ B ) $] \times \mathrm{S} 62\} \times \mathrm{G} .80$ and G.94 x G.93 gave the highest values for fiber strength at the conventional planting date, meanwhile, the crosses Suven x G.93 then CB58 x G.80 gave the highest values for fiber strength at the late planting date. The effect of the interaction between genotypes and planting date, caused the highest highly significant reduction in fiber strength of the cross G.94 x G.80 then G.94 x G.93 obtained at the conventional planting date compared to the late one. On the other hand, the crosses Suven x G.93 , Kar.2 x C.B58 and the parent G.93, respectively, gave highly significantly and significantly accepted fiber strength at late planting date as compared to the conventional one. Also, the results cleared differences in gene expression under different conditions. El-Helw ( 1990 ) reported that the additive effectswere important than the non-additive effects for fiber strength and fiber length.

With regard to fiber fineness, the parents Suven , C.B58, [ G.84 x ( G.70 x G51 B ) ] x S62 and G.93 did not show changes in Micronaire readings. Also, the crosses Kar. $2 \times$ Suven, Kar. $2 \times$ C.B58 , Kar. 2 x \{ [ G.84 x ( G.70 x G51 B ) ] x S62 \}, Kar.2 x G.80, Kar.2 x G.93, Suven x C.B58, Suven x G.94, Suven x G.80, Suven x G.93, C.B58 $\times\{[$ G.84 $\times(\mathrm{G} .70 \times \mathrm{G} 51 \mathrm{~B})] \times \mathrm{S} 62\}$, C.B58 $\times \mathrm{G} .80, \mathrm{C} . \mathrm{B} 58 \times$ G.93 , G.94 x \{ [ G.84 x ( G.70 x G51 B ) ] x S62 \}, G.94 x G.80 , G.94 $\times$ G.93 and \{ [ G.84 x ( G.70 x G51 B ) ] x S62 \} x G.80 showed statistically unchanged Micronaire values. These results cleared out that the fiber fineness was not negatively affected by delay of planting date of the above mentioned genotypes. On the other hand, the parent Kar.2 and the cross G.80 x G.93 exhibited negative change in fineness in the late planting date, while the parents $\mathrm{G} .94$ and $\mathrm{G} .80$ and the cross Kar. $2 \times$ G.94, Suven $\times\{$ [ G.84 x ( G.70 x G51 B ) ] x S62 \}, G. $80 \times$ G.94, C.B58 $\times$ G.94 and \{ [ G.84 x ( G.70 x G51 B ) ] x S62 $\} \times$ G.93 showed positive change in fineness, lower Micronaire value at late planting compared to the conventional one.

\section{General and specific combining ability effects :}

The genotypic variability among the diallel crosses was partitioned into general (GCA) and specific (SCA) effects under each environment of planting date (Table 3 ). Selection of parents for desirable combining ability is the first step in breeding for genetic improvement of seed cotton yield and fiber properties. This study was carried out to answer 
the equation. Whether there is a need to test parents and crosses for combining ability under variable environments?

\section{General combining ability effects (GCA):}

Changes of GCA effect for seed cotton yield between delayed planting and conventional planting were observed in this study. The parent Kar.2 gave positive and significant GCA at the conventional planting date ( 3.13 ) that was changed to insignificant negative at the late planting date $(-0.27)$ while, under the conventional planting date the promising line [ G.84 x ( G.70 x G.51 B ) ] x S62 gave negative highly significant value ( -2.362$)$ that was changed to negative and insignificant $(-0.477)$ under the late planting date . Thus, it should warrant the need of testing and selection of parents for seed cotton yield under environment of delayed planting. Similar results were reported by Zeng and Pettingrew ( 2015 ) .

The results in Table (3) showed that the parental variety Kar.2 expressed highly significant general combining ability effects for all characters under both conditions except for earliness index at the conventional planting date and seed cotton yield at the late planting date. However, it was negative for plant height, lint percentage, boll weight, fiber length and fiber strength and only in conventional planting for fiber fineness.

Suven expressed insignificantly general combining ability effects for plant height, earliness index, boll weight and seed cotton yield under late planting date. However, Suven gave significantly positive general combining ability effects for plant height, earliness, seed cotton yield and fiber length at conventional planting date. The GCA values were not significant at late planting for the above mentioned traits and for the other fiber properties at both planting dates. Highly significant negative GCA effects were obtained for lint percentage at both planting dates of Suven cultivar.

GCA effects of C.B58 was insignificant for all studied traits at both planting dates except for that of earliness and lint percentage where it was highly significant negative and fiber length and strength at conventional planting date where it was significant negative .

With regard to Giza 94, positive highly significant GCA effects were present for lint percentage at both dates of planting, boll weight at late planting date and fiber fineness at conventional planting date. With concern to fiber length and fiber strength at late planting GCA effects were highly significant and significant negative for both traits, respectively.

At conventional planting date, the promising line [ $\mathrm{G} .84 \times$ ( $\mathrm{G} .70 \times$ G.51 B ) ] x S62 showed positive GCA effects for plant height, fiber strength and fiber fineness, that were significant and highly significant 
in that order, but it showed highly significant negative GCA effect for seed cotton yield at conventional planting date.

At late planting, highly significant GCA effects were obtained for fiber length and fiber fineness. This means that late planting exhibits the proof that this line can be general doner for both traits, while the conventional planting date was better to detect the unsuitability of this line for seed cotton yield (poor combiner).

The parental cultivar G.80 expressed negative and significantly general combining ability effects for all traits except for plant height and boll weight in both planting dates and fiber strength and fiber fineness at the conventional planting date that were insignificantly positive.

Giza 93 as parent cultivar gave significantly positive general combining ability effects for earliness index, seed cotton yield and fiber length in both planting dates as well as fiber strength at late planting date. The pervious results cleared that, cotton breeder can use some varieties (Suven, CB58 and Giza 93) to improve seed cotton yield under late planting date.

The obtained general combining ability results indicate that among the used parental cultivars, genotypes that could be good combiner for improvement of cotton cultivars suitable for late planting e.g. Kar.2 for earliness and shorter plant height, Suven for fiber length, CB58 for earliness, G.94 for lint percentage, boll weight, [G.84 x (G.70 x G.51 B) ] x S62 for fiber fineness , G.80 for earliness and G.93 for fiber length and fiber fineness.

Table 3: General combining ability effects of parental genotypes for yield, yield components and fiber traits in two planting dates

\begin{tabular}{|c|c|c|c|c|c|c|c|c|c|c|}
\hline Genotypes & \multicolumn{2}{|c|}{ Plant height (cm) } & \multicolumn{2}{|c|}{ Earliness index (\%) } & \multicolumn{2}{|c|}{ Lint percentage (\%) } & \multicolumn{2}{|c|}{$\begin{array}{l}\text { Seed cotton yield } \\
\text { (g)/plant }\end{array}$} & \multicolumn{2}{|c|}{ Boll weight (g.) } \\
\hline Karsheneski-2 & $-14.03^{\star \star}$ & $-9.40^{* \star}$ & 2.81 & $5.97 *$ & $-1.11^{\star \star}$ & $-0.72^{\star \star}$ & $3.13^{* \star}$ & -0.27 & $-0.20^{* \star}$ & $-0.35^{\star \star}$ \\
\hline C.B58 & 0.69 & 2.96 & $-9.08^{* \star}$ & $-4.73^{* \star}$ & $-1.30^{* \star}$ & $-0.81^{\star \star}$ & -0.85 & 0.53 & 0.06 & 0.03 \\
\hline Giza 94 & -1.25 & -1.63 & 2.68 & 0.78 & $1.76^{* \star}$ & $1.92^{\star \star}$ & 0.30 & -0.45 & 0.10 & $0.22^{\star \star}$ \\
\hline Giza 93 & 0.56 & 1.01 & $8.10^{\star \star \star}$ & $4.46^{* \star}$ & $-0.57^{\star \star}$ & $-1.14^{\star \star}$ & $1.52^{* \star}$ & $1.22^{\star \star}$ & -0.07 & 0.07 \\
\hline
\end{tabular}


Table 3: Cont.

\begin{tabular}{|c|c|c|c|c|c|c|}
\hline \multirow[t]{2}{*}{ Genotypes } & \multicolumn{2}{|c|}{$\begin{array}{l}\text { Fiber length } \\
\qquad(\mathrm{mm})\end{array}$} & \multicolumn{2}{|c|}{$\begin{array}{l}\text { Fiber strength } \\
\text { (g/tex) }\end{array}$} & \multicolumn{2}{|c|}{$\begin{array}{c}\text { Fiber fineness } \\
\text { ( Micronaire } \\
\text { value ) }\end{array}$} \\
\hline & $D_{1}$ & $D_{2}$ & $D_{1}$ & $D_{2}$ & $D_{1}$ & $D_{2}$ \\
\hline Karsheneski-2 & -0.29 & $-0.63^{\star \star}$ & $-0.93^{\star}$ & -0.51 & $-0.22^{\star \star}$ & 0 \\
\hline Suven & $0.55^{\star}$ & 0.20 & 0.55 & 0.55 & 0.04 & 0.06 \\
\hline C.B58 & $-0.46^{\star}$ & 0.03 & $-0.83^{\star}$ & 0.38 & 0.04 & 0 \\
\hline Giza 94 & -0.11 & $-0.80^{\star \star}$ & 0.02 & $-0.95^{\star}$ & $0.27^{\star \star}$ & 0.11 \\
\hline $\begin{array}{c}\text { [ G.84 x ( G.70 x G.51 B ) ] } \\
\text { x S62 }\end{array}$ & 0.35 & $0.48^{\star *}$ & $1.02^{*}$ & 0.44 & $0.16^{\star *}$ & $0.22^{\star \star}$ \\
\hline Giza 80 & $\overline{-}^{-}$ & $-0.75^{\star \star}$ & 0.23 & $-1.01^{*}$ & 0.03 & -0.11 \\
\hline Giza 93 & $1.07^{\star \star}$ & $1.48^{\star *}$ & -0.08 & $1.10^{\star}$ & $-0.32^{\star *}$ & $0 . \overline{2}^{\star *}$ \\
\hline
\end{tabular}

$\mathrm{D}_{1}$ and $\mathrm{D}_{2}$ conventional and late planting dates.

${ }^{*},{ }^{* *}$ Significant and highly significant at 0.05 and 0.01 probability levels, respectively.

\section{Specific combining ability effects (SCA) :}

Specific combining ability effects of the cross combinations are presented in Table (4).

Table 4: Specific combining ability for yield, yield components and fiber traits in two planting dates

\begin{tabular}{|c|c|c|c|c|c|c|c|c|c|c|}
\hline \multirow{2}{*}{ Genotypes } & \multicolumn{2}{|c|}{ Plant height (cm) } & \multicolumn{2}{|c|}{ Earliness index (\%) } & \multicolumn{2}{|c|}{ Lint percentage (\%) } & \multicolumn{2}{|c|}{$\begin{array}{l}\text { Seed cotton yield } \\
\text { (g)/plant }\end{array}$} & \multicolumn{2}{|c|}{ Boll weight (g) } \\
\hline & $\mathrm{D}_{1}$ & $\mathrm{D}_{2}$ & $\mathbf{D}_{1}$ & $\mathrm{D}_{2}$ & $\mathrm{D}_{1}$ & $\mathrm{D}_{2}$ & $\mathbf{D}_{1}$ & $\mathrm{D}_{2}$ & $\mathrm{D}_{1}$ & $\mathbf{D}_{2}$ \\
\hline Kar. $2 \times$ SUVEN & $12.57^{\star}$ & -8.37 & 6.94 & 1.93 & 0.63 & $-1.65^{\star \star}$ & 1.63 & 0.37 & -0.13 & 0.30 \\
\hline Kar. 2 × C.B58 & -9.79 & $-16.01^{\star \star}$ & 7.63 & $13.37^{\star \star}$ & -0.81 & $2.15^{\star \star}$ & $4.60^{\star \star}$ & 1.58 & 0.26 & 0.04 \\
\hline Kar. 2 x G. 94 & -1.60 & -7.67 & 9.12 & 4.53 & $1.13^{\star}$ & $1.90^{\star \star}$ & $9.62^{\star \star}$ & $4.39^{\star \star}$ & -0.01 & $-0.31^{\star}$ \\
\hline Kar. 2 x [ G.84 x ( G.70 x G.51 B ) ] x S62 & -8.54 & -6.42 & $10.42^{\star}$ & 6.76 & $-1.70^{\star \star}$ & -1.00 & $5.54^{\star \star}$ & 0.86 & -0.14 & -0.28 \\
\hline Kar.2x G.80 & $-15.21^{\star}$ & -5.17 & $12.09^{\star}$ & $8.90^{\star}$ & $2.77^{\star \star}$ & 0.15 & $4.18^{\star \star}$ & -1.04 & $-0.34^{\star}$ & 0.24 \\
\hline Kar.2 x G.93 & -2.15 & -4.06 & -2.92 & -3.97 & $0.88^{\star}$ & 0.31 & 1.52 & -0.38 & -0.11 & $-0.51^{\star \star}$ \\
\hline Suven $\times$ C.B58 & -7.29 & 10.52 & $9.65^{\star}$ & $12.42^{\star \star}$ & -0.59 & 0.21 & $4.26^{\star \star}$ & -1.15 & -0.16 & $-0.35^{\star}$ \\
\hline Suven x G. 94 & 2.15 & -3.65 & -4.49 & 7.13 & $1.30^{\star \star}$ & 0.04 & $6.99^{\star \star}$ & 2.21 & $-0.34^{\star}$ & $0.35^{\star}$ \\
\hline SUVEN x [ G.84 x ( G.70 x G.51 B ) ] x S62 & -1.04 & -9.9 & 6.14 & $-9.27^{\star}$ & $1.58^{\star \star}$ & $2.35^{\star \star}$ & 1.29 & $3.78^{\star \star}$ & $0.44^{\star}$ & -0.03 \\
\hline Suven x G.80 & 4.79 & -8.65 & 3.75 & -0.15 & -0.78 & 0.58 & -0.14 & -1.36 & -0.03 & -0.17 \\
\hline Suven x G.93 & 1.60 & -6.28 & -6.94 & 3.97 & -0.79 & $-1.49^{\star}$ & 2.28 & $3.04^{\star}$ & $0.43^{\star}$ & 0.20 \\
\hline C.B58 x G. 94 & -1.32 & 1.22 & -1.28 & -3.72 & $-1.09^{\star}$ & $-1.89^{\star \star}$ & -0.11 & $-2.50^{\star}$ & -0.05 & -0.13 \\
\hline C.B58 x [ G.84 x ( G.70 x G.51 B ) ] x S62 & 0.49 & $-11.28^{\star}$ & 8.10 & 5.47 & $1.94^{\star \star}$ & 0.33 & $4.02^{\star \star}$ & $-2.20^{*}$ & -0.11 & 0.14 \\
\hline C.B58 x G.80 & $12.57^{\star}$ & -2.53 & 4.42 & 1.45 & 0.24 & -1.02 & -2.20 & -0.10 & -0.11 & 0.12 \\
\hline C.B58 x G.93 & 6.88 & -5.17 & $12.05^{\star}$ & $10.87^{\star}$ & -0.15 & -0.41 & 0.38 & $6.13^{\star \star}$ & -0.01 & 0.02 \\
\hline G. $94 \times$ [ G.84 x ( G.70 x G.51 B ) ] x S62 & 3.68 & 8.3 & -1.20 & 3.72 & -0.32 & -0.49 & $-3.75^{\star}$ & -1.08 & -0.01 & -0.16 \\
\hline G. $94 \times$ G. 80 & -1.74 & -7.95 & 3.05 & -3.73 & $-1.83^{\star \star}$ & $-1.41^{\star}$ & 0.62 & -1.21 & 0.20 & 0.02 \\
\hline G. $94 \times$ G.93 & -4.93 & -6.84 & 2.24 & $-9.33^{\star}$ & -0.84 & $-2.08^{\star \star}$ & $-3.93^{\star \star}$ & -0.98 & -0.07 & -0.25 \\
\hline [ G.84 x ( G.70 x G.51 B ) ] x S62x G.80 & -7.43 & 8.3 & 6.68 & 8.04 & $1.50^{\star \star}$ & $-1.29^{\star}$ & -1.47 & 0.86 & -0.27 & $0.35^{\star}$ \\
\hline [ G.84 x ( G.70 x G.51 B ) ] x S62x G.93 & -0.63 & 9.41 & 0.26 & 0.41 & $0.96^{\star}$ & -0.41 & 0.40 & -0.27 & 0.02 & $-0.35^{\star}$ \\
\hline G. $80 \times$ x.93 & -4.79 & $11.91^{\star}$ & 1.41 & 8.59 & -0.69 & $3.07^{\star \star}$ & -0.58 & -0.97 & $0.39^{\star}$ & 0.30 \\
\hline
\end{tabular}


For plant height, the cross combinations Kar.2 $\times$ Suven and CB58 x G.80 showed high significant and positively SCA at conventional planting date but the crosses Kar.2 $\times$ CB58 and CB58 $\times\{$ [ G.84 x ( G.70 x G.51 B ) ] x S62 \} showed negative and significant SCA for short plant even under late planting conditions .

With regard to earliness index the four crosses Kar.2 $\times$ \{ [ G.84 x ( G.70 x G.51 B ) ] x S62 \}, Kar.2 x G.80, Suven x CB58 and CB58 $x$ G.93 showed significant positive SCA effects at conventional planting date. The crosses Kar.2 x CB58 and Suven x CB58 exhibited highly significant one at late planting, while Kar.2 x G.80 and CB58 x G.93 exhibited only significant positive effects at that late planting date. All that results indicated earliness. But, two other crosses showed negative SCA effect at late planting; namely Suven $\times$ \{ [ G.84 x ( G.70 x G.51 B ) ] x S62 \} and G.94 x G.93. They could be used to produce earlier cottons under late planting .

For lint percentage, twelve crosses exhibited significant positive SCA effects; eight crosses exhibited significant positive SCA effects under conventional planting date conditions and four crosses under late planting date conditions. The best crosses were Kar. $2 \times$ G.94, Kar. 2 x G. 80 , Kar. 2 x G.93, Suven x G.94, Suven x \{ [ G.84 × ( G.70 x G.51 B ) ] x S62 \}, CB58 x \{ [ G.84 x (G.70 x G.51 B ) ] x S62 \}, \{ [ G.84 × ( G.70 × G.51 B ) ] × S62 \} × G.80 and \{ [ G.84 × ( G.70 × G.51 B ) ] x S62 \} x G.93 for lint percentage at conventional planting date and G.80 x G.93, Suven x \{ [ G.84 x ( G.70 x G51 B ) ] x S62 \}, Kar.2 $\times$ CB58 and Kar.2 $x$ G.94 at late planting dates .

For Seed cotton yield, eleven crosses exhibited significant and highly significant positive SCA effects; seven crosses under conventional planting date condition, as well as, four crosses under late planting date condition. The best cross for seed cotton yield was Kar. 2 x G.94 followed by Suven x G.94 and Kar. 2 × \{ [ G.84 × ( G.70 x G.51 B ) ] x S62 \} at conventional planting date and C.B58 x G.93 followed by Kar.2 x G.94 and Suven x \{ [ G.84 x ( G.70 x G.51 B ) ] x S62 $\}$ at late planting date.

The change of SCA effect for seed cotton yield between delayed planting and conventional planting was observed in this study by the cross Kar.2 x G.94 that gave positive and highly significant ( $9.62^{* *}$ ) SCA effects at conventional planting date and significant ( $4.39^{\star}$ ) at late planting date, while, the crosses Suven x G.94 gave positive and highly significant ( $6.99^{* *}$ ) SCA effect under conventional planting date that was changed to not significant ( 2.21 ) at late planting date. Thus, it should warrant the need of testing and selection of crosses for seed cotton yield under environment of delayed planting.

For boll weight, five crosses exhibited significant positive SCA effects under conventional planting date and late planting date 
conditions; respectively. The desirable crosses were Suven $\mathrm{x}\{$ [ $\mathrm{G} .84 \mathrm{x}$ ( G.70 x G.51 B ) ] x S62 \}, Suven x G.93 , G.80 × G.93 at conventional planting date and Suven $\times$ G.94 and \{ [ G.84 × ( G.70 × G.51 B ) ] x S62 \} x G.80 at late planting dates for boll weight.

Table 4 : Cont.

\begin{tabular}{|c|c|c|c|c|c|c|}
\hline \multirow{2}{*}{ Genotypes } & \multicolumn{2}{|c|}{ Fiber length $(\mathrm{mm})$} & \multicolumn{2}{|c|}{ Fiber strength (g/tex) } & \multicolumn{2}{|c|}{ Fiber fineness ( Micronaire value ) } \\
\hline & $D_{1}$ & $\mathrm{D}_{2}$ & $\mathrm{D}_{1}$ & $\mathrm{D}_{2}$ & $\mathrm{D}_{1}$ & $\mathrm{D}_{2}$ \\
\hline Kar.2 $\times$ Suven & $2.71^{\star \star}$ & 0.72 & $2.41^{\star}$ & 1.01 & $0.33^{\text {** }}$ & -0.06 \\
\hline Kar. $2 \times$ C. .858 & $1.19^{* \star}$ & $1.39^{\star \star}$ & -0.25 & 1.68 & $0.26^{*}$ & 0 \\
\hline Kar. 2 x G. 94 & $0.48^{*}$ & $1.22^{\star}$ & -0.36 & 2.01 & 0.12 & -0.11 \\
\hline Kar.. $2 \times[$ G. $.84 \times(G .70 \times$ G.51 B $)] \times \mathrm{S} 62$ & 0.24 & $1.44^{\star \star}$ & 0.54 & 2.63 & 0.04 & -0.22 \\
\hline Kar.2x G.80 & $-1.43^{* \star}$ & -0.83 & -1.57 & -1.43 & 0.03 & 0.11 \\
\hline Kar. $2 \times$ G. 93 & $1.42^{* \star}$ & -0.06 & -0.56 & -1.04 & 0.07 & 0.28 \\
\hline Suven x C.B58 & $0.78^{* \star}$ & -0.44 & -0.73 & -0.88 & 0.03 & -0.06 \\
\hline Suven x G. 94 & $1.07^{* \star}$ & 0.39 & $2.31^{\star}$ & 0.96 & 0.06 & 0.33 \\
\hline Suven $\times[$ G. $.84 \times(G .70 \times$ G.51 B $)] \times S 62$ & $0.52^{\star}$ & -0.39 & 1.61 & 1.07 & 0.16 & -0.28 \\
\hline Suven x G.80 & $0.85^{* \star}$ & 0.83 & 1.00 & 0.01 & -0.09 & 0.06 \\
\hline Suven x G.93 & -0.32 & 0.11 & -1.39 & $4.90^{\star \star}$ & 0.07 & 0.22 \\
\hline C.B58 x G. 94 & -0.27 & $2.56^{\star \star *}$ & -1.35 & 0.13 & -0.05 & -0.11 \\
\hline C.B58 × [ G. $84 \times($ G. $70 \times$ G. .51 B $)] \times$ S62 & $0.77^{* \star}$ & -0.22 & 1.50 & -1.76 & 0.03 & -0.22 \\
\hline C.B58 x G.80 & $1.01^{\star \star}$ & 1.00 & $2.29^{*}$ & $3.68^{* \star}$ & -0.09 & 0.11 \\
\hline C.B58 x G.93 & 0.35 & 0.28 & 1.45 & -1.43 & 0.08 & 0.28 \\
\hline G. $94 \times[$ G. $84 \times($ G. $70 \times$ G. .51 B $)] \times$ S62 & $-0.46^{\star}$ & 0.11 & -1.01 & -1.93 & -0.11 & 0.17 \\
\hline G. $94 \times$ G. 80 & $0.44^{*}$ & $-1.17^{*}$ & 1.28 & -1.49 & -0.11 & $0.50^{*}$ \\
\hline G. $94 \times$ G.93 & $2.01^{\star \star}$ & 0.11 & $3.04^{\star \star}$ & -1.60 & -0.01 & -0.33 \\
\hline [ G. $.84 \times(\mathrm{G} .70 \times$ G. .51 B $)] \times \mathrm{S} 62 \times \mathrm{G} .80$ & $0.88^{* *}$ & -0.44 & 1.73 & 0.63 & 0.13 & 0.39 \\
\hline [ G. $.84 \times(\mathrm{G} .70 \times$ G. .51 B $)] \times \mathrm{S} 62 \times \mathrm{G} .93$ & -0.20 & -0.17 & -0.56 & 1.01 & 0.11 & 0.06 \\
\hline G. $80 \times$ G.93 & 0.38 & 0.06 & 0.33 & -1.54 & -0.24 & 0.39 \\
\hline
\end{tabular}

$\mathrm{D}_{1}$ and $\mathrm{D}_{2}$ conventional and late planting dates.

*, ** Significant and highly significant at 0.05 and 0.01 probability levels, respectively.

For fiber length, all crosses except for six crosses under conventional planting date conditions as well as, five crosses under late planting date conditions exhibited significant SCA effects. The best crosses were Kar. 2 x Suven followed by G.94 x G.93 for fiber length at conventional planting date and C.B58 $\times$ G.94 followed by Kar.2 x \{ [ G.84 x ( G.70 x G.51 B ) ] x S62 \}, Kar.2 × C.B58 at late planting dates.

For fiber strength, four crosses exhibited positive significant SCA effects under conventional planting date conditions, as well as, two crosses under late planting date condition. The best crosses were G.94 x G.93, Kar.2 x Suven, Suven x G.94 and C.B58 x G.80 for fiber strength at conventional planting date and Suven $\times$ G.93 followed by C.B58 x G.80 at late planting date. 
Concerning fiber fineness (Micronaire value), three crosses and two crosses exhibited significant SCA effects under conventional planting date conditions and late planting date conditions, respectively . The best crosses were G. $80 \times$ G.93, Suven $\times\{$ [ G.84 × ( G.70 x G.51 B ) ] x S62 \} then Suven x G.93 , G.80 x G.93 in fineness at conventional planting date and Suven x G.94 and \{ [ G.84 x ( G.70 x G.51 B ) ] x S62 \} x G.80 at late planting dates. Amer ( 1995 ) observed that additive genetic effects showed great portion of variance for fiber fineness and fiber strength.

The characters showing significant genotypic differences were further analyzed for GCA and SCA effects, as defined by Sprague and Tatum (1942). These results reported change performance of crosses under different environment conditions. Generally, changes of combining ability for yield and fiber properties were observed in this study under both different planting dates. The breeders should select suitable parents or crosses which can realize their desire with the late planting to increase affectivity of selection in segregating generations. The parents (Suven, CB58 and Giza 93) were good combiners under late planting dates. Also, the best crosses were Kar. $2 \times \mathrm{G} .94$, Suven $\times$ \{[ G.84 x ( G.70 x G.51 B ) ] x S62\}, Suven x G.93 and CB58 x G.93 for seed cotton yield under late planting date. In addition, these crosses are characterized by high yield under late planting date. The parent G.93 and the crosses Suven x G.93, C.B58 x G.93 and \{ [ G.84 × ( G.70 x G.51 B ) ] x S62 \} × G.93 exhibited the best values for fiber traits. Cotton breeders can use these hybrids to improve breeding programs and to select the most promising genotypes for late-planting date. These crosses could be exploited in breeding program aiming to improve late-planting tolerance. This is necessary for better cultivated land use efficiency.

\section{REFERENCES}

Ahuja S.L., O. P. Tuteja, 2000. Variability and association analysis for chemical components imparting resistance in $\mathbf{G}$. hirsutum L. cotton . J. Cotton Res. Dev, 14(10), 19-22.

Ali, S.A. and A.F. El Sayed, 2001. Effect of sowing dates and nitrogen levels on growth, earliness and yield of Egyptian cotton cultivar Giza 88. Egypt. J. Agric Res., 79(1): 221-232.

Amein M.M.M., M.I. Masri, A.M.R. Abd El-Bary and S.S. Attia, 2013. Combinig ability and heterosis for yield and fiber quality traits in cotton (Gossypium barbadense L.) . Egypt. J. plant breed. 17 (5), 129-141.

Elayan E.D., Sohair, A.M.A. Abdalla, Abdel-Gawad,S.D. Nadia and A.E. Faramawy Wageda, 2015 . Effect of delaying planting date on yield, fiber and yarn quality properties in some cultivars and promising crosses of Egyptian cotton . 
American-Eurasian J. Agric. \& Environ. Sci., 15 (5): 754763.

Elayan, Sohair, E.D., M. Abdalah, Amany and A. El-Ssadi, Sawsan, 2008. Effect of three sowing dates on different characteristics of four Egyptian cotton cultivars. Agric. Sci. Mansoura Univ., 33(3): 1721-1736.

Green C. C. and T. W. Culp, 1990. Simultaneous Improvement of Yield, Fiber Quality, and Yarn Stregth in Upland Cotton. Vol. 30 No. 1, p. 66-69.

Griffing, B. (1956). Concepts of general and specific combining ability in relation to diallel crossing systems. Anst. J. Biol. Sci. 9 .

Khan T. M. , J. Farooq, A. Mahmood, R. N. Abbas, W. Nazeer , A. Farooq, Z. Hasnain, M. N. Akhtar, 2011. Exploring influential plant traits for enhancing upland cotton yield under salt stress . Front. Agric. China 2011, 5(4): 443-449.

Linghe Z., T. P. William, 2015. Combining ability, heritability, and genotypic correlations for lint yield and fiber quality of Upland cotton in delayed planting. Field Crops Research 171 (2015) 176-183 .

Snedecor, G.W. and W.G. Cochran, 1982. Statistical Methods, lowa state., Univ. Press., USA.

Soomro. A.R., M.H. Channa, A.A. Channa, G.H. Kalwar, G.N. Dayo and A.H. Memon, 2000. The effect of different sowing dates on the yield of newly developed strain under climatic conditions of Ghotki, Sindh. The Pakistan Cottons, 44: 25-31.

Sprague G. F. and L. A. Tatum, 1942. General vs. specific combining ability in single crosses of corn. J. Amer. Soc. Agron. 34:923-32.

Tunio, K.L., A.H. Ansari, S.M. Qayyum, M.N. Kalwar and W.A. Khan, 1992. Effect of different sowing dates on the yield components of cotton ( Gossypium hirsutum. L. ) cultivars. Pak. J. Agril. Eng. Vet. Sci., 8: 24-27 .

Tuteja O.P., P. Luthra and S. Kumar, 2003. Combining ability analysis in upland cotton (Gossypium hirsutum) for yield and its components . Indian Agri. Sci. 73 (12), 671-675.

Wenqing, Z., Y. Wang, H.J. Shu and Z. Zhou, 2012. Sowing date and boll position affected boll weight, fiber quality and fiber physiological parameters in two cotton (Gossypium hirsutum L.) cultivars. African J. of Agric., Res., 7(45): 6073-6081.

Yehia W.M.B. and S.S. Hassan, 2015. Genetic analysis of yield and its components of some Egyptian cotton crosses (Gossypium barbadense L.). Egypt. J. Plant Breed. 19(4):999-1010.

Zeng L. and W.T. Pettingrew, 2015. Combining ability, heritability, and genotypic correlations for lint yield and fiber quality of 
Upland cotton in delayed planting. Field Crops Res. 171:176-183.

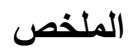

أداء بعض التراكيب الوراثية من القطن تحث مواعيد الزراعة التقليدية والمتأخرة

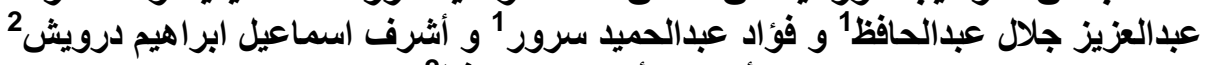

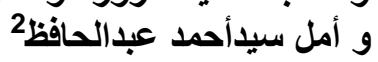

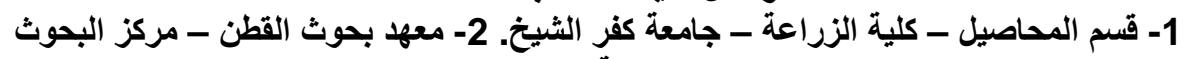

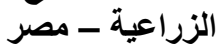

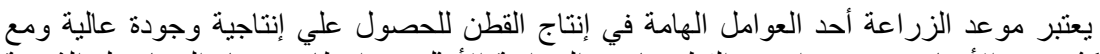

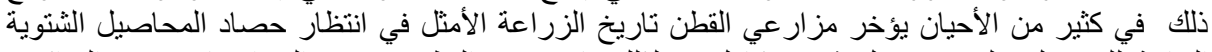

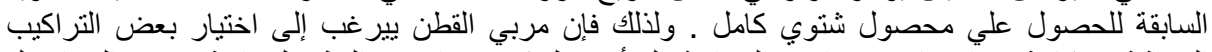

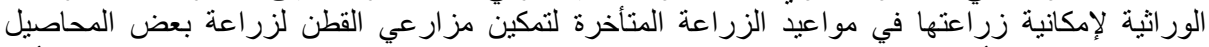

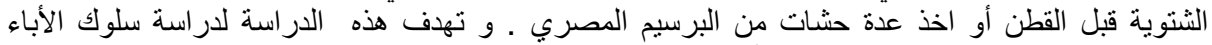

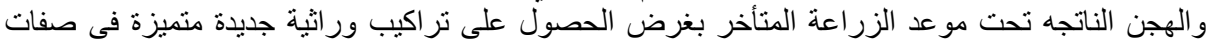

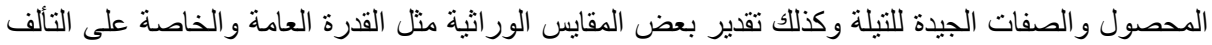

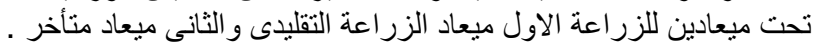

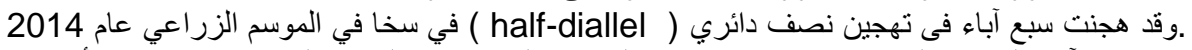

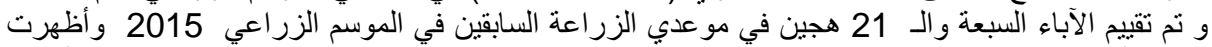

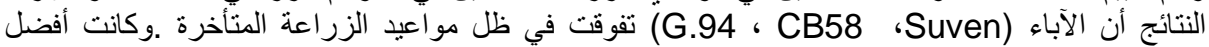

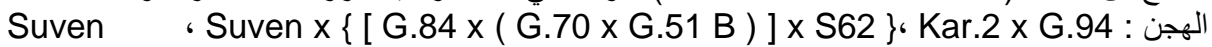
G.93 لصفة محصول القطن الزهر تحت موعد الزر ج CB58 X G.93، x G.93

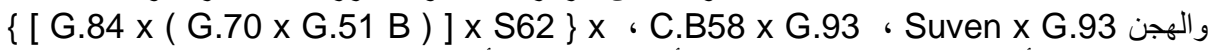

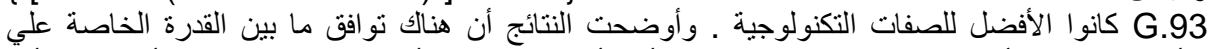

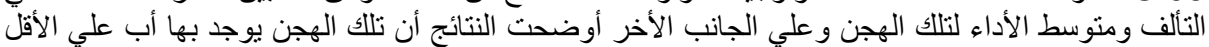

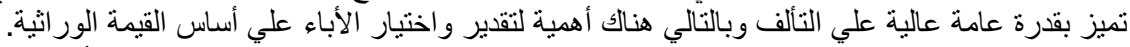

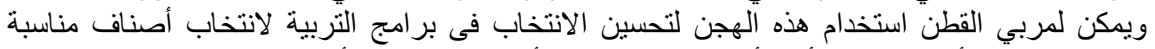

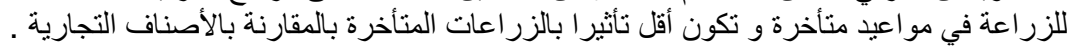

